\title{
Effect of Actinomycin $D$ and Chloramphenicol on the Induction of the Malate Decarboxylase System in Lactobacillus thermobacterium 5 (CNRZ) 313
}

\author{
By ANA M. STRASSER DE SAAD, G. OLIVER AND \\ AIDA A. PESCE DE RUIZ HOLGADO \\ Institute of Microbiology, Faculty of Biochemistry, Chemistry and Pharmacy, \\ National University of Tucumán, Argentine Republic
}

(Received I7 September 1974; revised 6 January 1975)

SUMMARY

This paper presents data on the induction of malate decarboxylase in Lactobacillus thermobacterium and the effect of chloramphenicol and actinomycin D on the induction.

\section{INTRODUCTION}

Experimental data and basic information on inducible enzyme systems in microorganisms are available (Jacob \& Monod, 196I; Pollock \& Kramer, I958; Englesberg et al. 1965; Schwartz, 1967; Cove, 1966) but no specific information has been given concerning the Lactobacilli species. We present data on the induction of the malate decarboxylase (MDC) system in Lactobacillus thermobacterium 5 (CNRZ) 313.

It is of interest that the decarboxylation of the L-malic acid has been used as a taxonomic characteristic for the classification of certain groups of Lactobacilli (Keddie, 1959).

\section{METHODS}

Organism and growth conditions. Lactobacillus thermobacterium 5 (CNRZ) 3I 3 (Raibaud et al. 1973) was used. For good growth, transfer to LAPTg medium (see below) every $12 \mathrm{~h}$ was necessary. After $8 \mathrm{~h}$ incubation at $37^{\circ} \mathrm{C}, 0 \cdot 2 \mathrm{ml}$ of the resulting culture was added to $5 \mathrm{ml}$ of fresh LAPTg medium and stored at $4{ }^{\circ} \mathrm{C}$.

Medium. LAPT medium, and LAPTg medium, i.e. LAPT medium + glucose (Raibaud et al. 196I) were used. When required, $0.5 \% \mathrm{~L}$-malic acid and other supplements were added.

Chemicals. Tryptone, yeast extract and peptone were obtained from Oxoid, actinomycin D and mercaptoethanol from Sigma, glucose from Carlo Erba, L-malic acid from NBC, Tween 80 from Fluka and chloramphenicol from Parke-Davis.

Preparation of cell suspension. Lactobacillus thermobacterium was grown in LAPTg with and without L-malic acid at $37^{\circ} \mathrm{C}$ for $8 \mathrm{~h}$. Cells were removed by centrifugation at $3020 \mathrm{~g}$ for $20 \mathrm{~min}$, washed with $0 . \mathrm{I} \%$ mercaptoethanol and finally resuspended in mercaptoethanol to a cell concentration of $10 \%$ transmittance measured at $560 \mathrm{~nm}$ with a Spectronic 20 spectrophotometer.

Enzyme activity. The activity was determined by measuring the $\mathrm{CO}_{2}$ released at $37^{\circ} \mathrm{C}$ with a Gilson differential respirometer at regular intervals, using the reaction systems shown in Table I. 
Accumulation of transcription intermediates. LAPTg medium containing L-malic acid and $2 \mu \mathrm{g}$ chloramphenicol $(\mathrm{Cm}) / \mathrm{ml}$ was inoculated with a suspension of cells grown without the inducer, and incubated at $37^{\circ} \mathrm{C}$. $\mathrm{Cm}$ is thought to block translation on bacterial $70 \mathrm{~S}$ ribosomes, but not transcription; therefore since samples were drawn after I0, 20, 40 and $60 \mathrm{~min}$ of incubation, we assumed that in each case different amounts of transcription intermediates were accumulated in the cells. The cells were immediately collected, washed and resuspended as described.

Translation of the previously accumulated transcription intermediates. Each of the resulting cell suspensions obtained as indicated above was used for the inoculation of LAPTg medium supplemented with L-malic acid and $2 \mu \mathrm{g}$ actinomycin D (Am)/ml, which blocks transcription but not translation. The systems were incubated and the enzyme activity measured.

\section{RESULTS}

\section{Induction of the malate decarboxylase system}

Experiments were performed as shown in Table I, using cells grown without inducer. The results (Fig. I) can be summarized as follows: besides the inducer, glucose and LAPT medium were necessary for induction; the induction curve shows an absolute lag period of Io min followed by an acceleration lag period of $30 \mathrm{~min}$; the addition of $\mathrm{Cm}$ inhibited the joint action of glucose, LAPT and L-malic acid on the induction.

Experiments performed as shown in Table I, using cells grown in the presence of the inducer (Fig. 2): the absence of the absolute lag period is apparent; up to approximately $30 \mathrm{~min}$ of incubation no substantial difference in activity appears in the systems, even if $\mathrm{Cm}$ is present; the system containing LAPT and glucose, but not $\mathrm{Cm}$, shows a marked increase in activity after approximately $30 \mathrm{~min}$.

Influence of Am on the induction - cells grown without the inducer (Table I and Fig. 3): Am added along with the other components of the system completely inhibits the enzyme activity from the beginning; the inhibitory effect of Am when added to the systems at different intervals appears immediately after the addition of the antibiotic.

Cells grown in the presence of the inducer (Table I, Fig. 4): enzyme activity is detected even if Am is added from the beginning; when Am is added to the system after 10 or $20 \mathrm{~min}$ of incubation the enzyme activity increases accordingly.

Cells with different amounts of accumulated transcription intermediates: there is a direct correlation between enzyme activity and amount of transcription intermediates accumulated in the cells; once the pool of transcription intermediates is exhausted the synthesis of the enzyme(s) stops.

\section{DISCUSSION}

Under the experimental conditions tested L-malic acid is able to produce induction of the MDC system only in the presence of glucose and LAPT medium, the latter probably because of the amino acids (Halvorson \& Spiegelman, 1953; Monod \& Cohn, 1952) contained in yeast extract. The results show that the inhibitory effect of $\mathrm{Cm}$ is apparent immediately after the absolute lag in cells without previous induction (Fig. I). If the antibiotic is added after an adequate period of induction (Fig. 2), $\mathrm{Cm}$ has no effect on the activity of the enzyme(s) already formed in the cells but in some way it blocks enzyme synthesis.

Similar conclusions may be drawn when the effect of Am on the induction is tested (Figs. 3 and 4), suggesting that inhibition occurs at an early stage of protein synthesis. This 


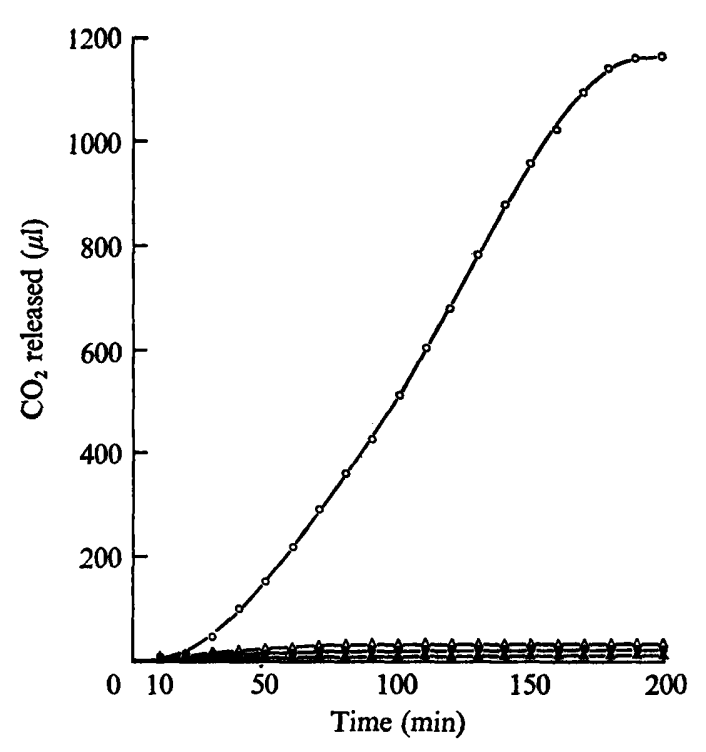

Fig. I

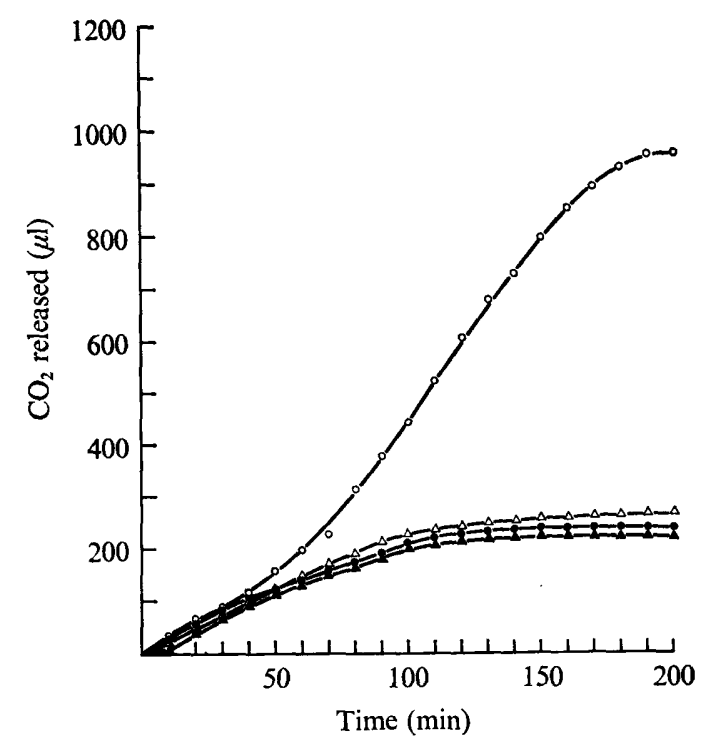

Fig. 2

Fig. I. Induction of the MDC system. Influence of different reaction mixtures (Table I) on the induction of cells grown on LAPTg medium without the addition of L-malic acid (inducer). Enzyme activity measured by means of a differential respirometer and expressed as the $\mathrm{CO}_{2}$ released. $\bullet$, Reaction mixture I, with glucose; $\triangle$, reaction mixture 2, with LAPT medium; $\bigcirc$, reaction mixture 3, with LAPT medium and glucose; $\Delta$, reaction mixture 4 , with LAPT medium, glucose and $\mathrm{Cm}$.

Fig. 2. Induction of the MDC system. Influence of different reaction mixtures (Table I) on the induction of cells obtained using LAPTg medium containing L-malic acid. For further details and symbols see the legend to Fig. I.

Table I. Composition of the reaction mixtures used in the experiments whose results are presented in Figs. I and 2

O.I M-phosphate buffer, $\mathrm{pH} 5 \cdot 5$

0.24 M L-malic acid

0.24 M-glucose

LAPT medium

Chloramphenicol ( $2 \mu \mathrm{g} / \mathrm{ml}$ final concn)

Water

Cell suspension
Composition $(\mathrm{ml})$ of reaction mixture nos.

$\begin{array}{cccc}\text { I } & 2 & 3 & 4 \\ 0.5 & 0.5 & 0.5 & 0.5 \\ 0.5 & 0.5 & 0.5 & 0.5 \\ 0.5 & - & 0.5 & 0.5 \\ - & 0.2 & 0.2 & 0.2 \\ - & - & - & 0.1 \\ 0.5 & 0.8 & 0.3 & 0.2 \\ 0.5 & 0.5 & 0.5 & 0.5\end{array}$

hypothesis has further support from the experimental data displayed in Fig. 5, which show a direct correlation between the amount of transcription intermediates, probably mRNA, accumulated in the cells and the resulting enzyme activity measured after the addition of Am. Thus, it seems likely that when the pool of transcription intermediates is exhausted the synthesis of the enzyme(s) is no longer possible due to the inhibitory effect of Am on transcription. These data suggest that the induction of the MDC system in L. thermobacterium 5 (CNRZ) 313 occurs at the transcription level, probably through the same or similar general mechanisms as have been described in other micro-organisms. 


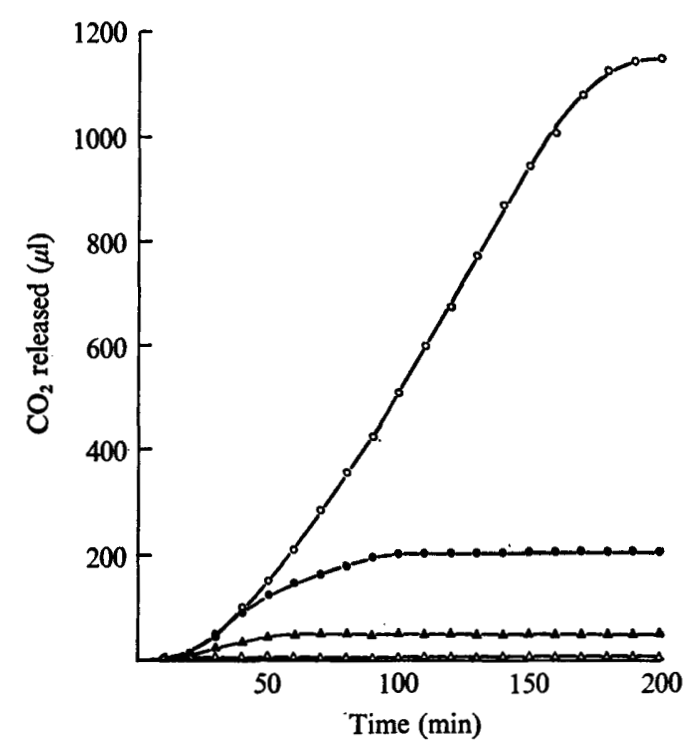

Fig. 3

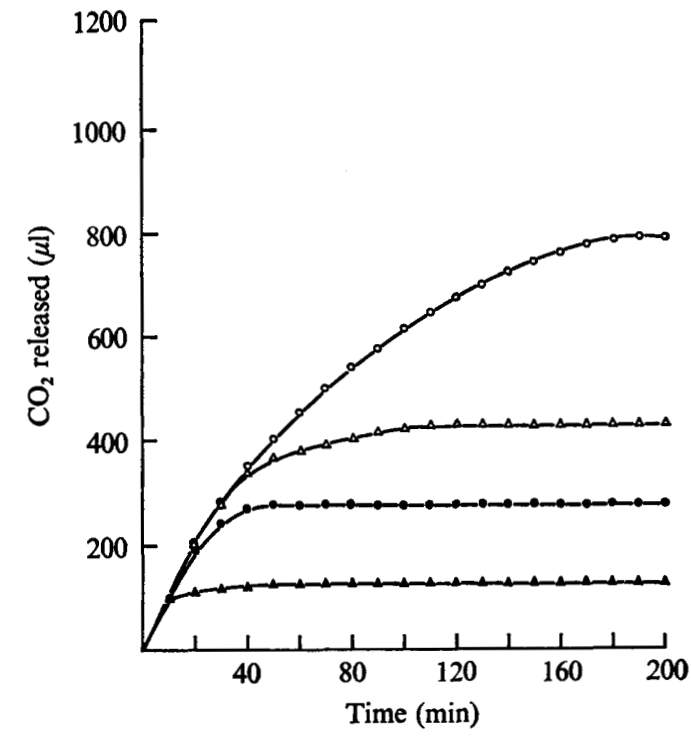

Fig. 4

Fig. 3. Effect of Am on the induction of cells obtained using LAPTg medium without the addition of L-malic acid. Reaction mixture, containing LAPT medium, glucose, L-malic acid and Am, was added at various times. Taking the time that incubation commenced in the differential respirometer as time zero, Am was added at the following times: $\triangle, 0 \mathrm{~min} ; \Delta, 10 \mathrm{~min} ; 0,20 \mathrm{~min} .0$, Control without Am.

Fig. 4. Effect of Am on the induction of cells obtained using LAPTg medium containing L-malic acid. For further details and symbols see the legend to Fig. 3 .

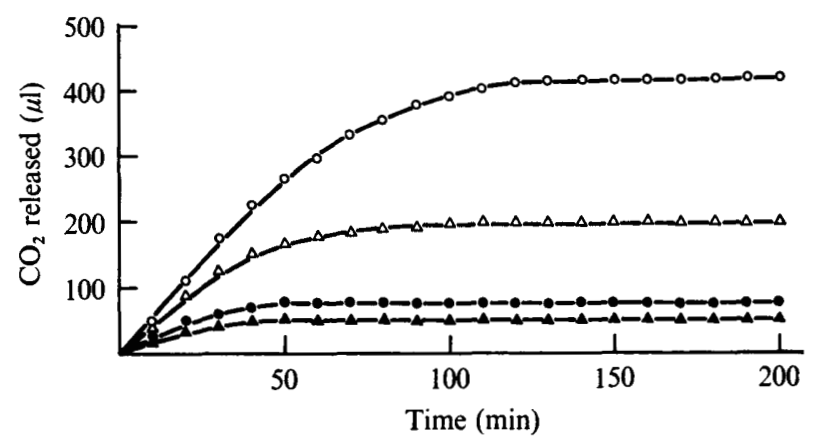

Fig. 5. Determination of the possible induction level. Cells grown without the inducer were used to inoculate LAPT medium containing glucose, $\mathrm{L}$-malic acid and $\mathrm{Cm}$ (to inhibit translation but not transcription). Samples were taken after 10, 20,40 and $60 \mathrm{~min}$ of incubation and the cells were collected, washed, transferred to LAPT medium supplemented with glucose, L-malic acid and Am (to inhibit transcription but not translation), and the enzyme activity was measured as usual. Taking into account the times of incubation in the presence of $\mathrm{Cm}$, the results were as follows: $\triangle, 10 \mathrm{~min}$; $0,20 \mathrm{~min} ; \triangle, 40 \mathrm{~min} ; 0,60 \mathrm{~min}$. 
This research was partially supported with grants Nos. 05I-L-33 and 3843a/7I from Secretaría de Ciencia y Técnica and Consejo Nacional de Investigaciones Científicas y Técnicas (R. Argentina), respectively. Strain L. thermobacterium 5 (CNRZ) 313 was kindly supplied by Dr Pierre Raibaud.

\section{REFERENCES}

Cove, D. J. (1966). The induction and repression of nitrate reductase in the fungus Aspergillus nidulans. Biochimica et biophysica acta $113,5 \mathrm{I}-56$.

ENGlesberg, E., IrR, J., Power, J. \& LeE, N. (1965). Positive control of enzyme synthesis by gene C in the L-arabinose system. Journal of Bacteriology 90, 946.

Halvorson, H. O. \& Spiegelman, S. (I953). The effect of free amino acids basal levels on the induced synthesis of enzymes. Journal of Bacteriology 65, 496-504.

JACOB, F. \& MONOD, J. (196I). Genetic regulatory mechanisms in the synthesis of proteins. Journal of Molecular Biology 3, 318-356.

KeDdiE, R. M. (1959). The properties and classification of lactobacilli isolated from grass and silage. Journal of Applied Bacteriology 22, 403-416.

Monod, J. \& Coнn, M. (1952). La biosynthèse induite des enzymes. Advances in Enzymology 13, 67-I 19. Edited by F. F. Nord. New York: Interscience Publishers.

Pollock, M. R. \& Kramer, M. (1958). Intermediates in the biosynthesis of bacterial penicillinase. Biochemical Journal 70, 665-68I.

Raibaud, P., Caulet, M., Galpin, J. B. \& Mocquot, G. (I96I). Studies on the bacterial flora of the alimentary tract of pigs. II. Streptococci: selective enumeration and differentiation of the dominant group. Journal of Applied Bacteriology 24, 285-306.

Raibaud, P., Galpin, J. V., Ducluzeau, R., Mocquot, G. \& Oliver, G. (1973). Le genre lactobacillus dans le tube digestif du rat. I. Caractères des souches homofermentaires isolées de rats holo et gnotoxéniques. Annales de Microbiologie (Institut Pasteur) r24A, 83-109.

Schwartz, M. (1967). Aspects biochimiques et génétiques du metabolisme du maltose chez E. coli $K_{12}$. Thèse de doctorat. Université de Paris, France. 